\title{
Relationships Between University Characteristics and Early Job Outcomes of Accountants ${ }^{\star \star}$
}

\section{STEPHEN M. COLARELLI*, ROGER A. DEAN ${ }^{\dagger}$, CONSTANTINE KONSTANS $\triangle$}

\begin{abstract}
This study undertook an examination of relationships among university characteristics and job offers, employment status, job attitudes, and job performance of newly-hired accounting graduates. It was found that university characteristics are generally not related to job attitudes and job performance. A few characteristics correlated with the total number of job offers, and characteristics associated with wealth and status correlated with receiving job offers from prestigious accounting firms. Several explanations are suggested for the results-including threshold effects, prestige effects, and influence of the work environment.
\end{abstract}

\section{Résumé}

Nous avons examiné les rapports existant entre les caractéristiques universitaires et les offres d'emplois, le statut à l'embauche, les attitudes et aptitudes professionnelles de comptables diplômés nouvellement embauchés.

* Associate Professor of Psychology, Central Michigan University

$\dagger$ Professor of Administration,School of Commerce, Economics, and Politics, Washington and Lee University

$\Delta$ Executive Director, Professional Development, KPMG Peat Marwick

** This research was funded in part by a Summer Fellowship from Central Michigan University to Stephen Colarelli and a Glenn Grant from Washington and Lee University to Roger Dean. The authors gratefully acknowledge the comments of William Balzer, Terry Beehr, Hajime Otani, Sara Rynes, and Robert Sinclair on earlier versions of the manuscript. We also thank Carl Lee for his assistance with the statistical analyses and Todd Claringbold for his help with the literature search. 
Les caractéristiques universitaires n'ont généralement pas de rapport avec les attitudes et aptitudes professionnelles. Certaines caractéristiques s'appliquent à l'ensemble des offres d'emplois; principalement d'autres, liées à l'argent et au standig permettent de faire le lien avec l'embauche par les bureaux les plus prestigieux. Nous fournissons plusieurs explications de ces résultats et nous analysons les effets de transition, les effets de prestige et l'influence de l'environment professionel.

Countries with established higher education systems differentiate universities on a variety of characteristics (Burn, Altbach, Kerr, \& Perkins, 1971; Birnbaum, 1983; Skolnik, 1986). Some characteristics are salient to a particular country. For example, Canadians distinguish their universities by whether they are French-speaking or English-speaking (Church \& Gillingham, 1985). Americans and Japanese distinguish between public and private universities (Burn et a1., 1971; Hall, 1982). On the other hand, other university characteristics may be salient across many countries. Such characteristics might include size, wealth, quality of entering students, and selectivity (Burn et al., 1971).

University characteristics are important because young people often select a university based on its standing on salient characteristics (Church \& Gillingham, 1985; Sanders, 1986). Also, many students, their parents, and university officials believe that university characteristics influence job opportunities and job behaviour. For example, students and their parents often think that different types of universities afford unique career advantages (Bauer et al., 1988; Carnegie Foundation for the Advancement of Teaching, 1986; Sanders, 1986). University administrators foster this belief by touting the career advantages that their schools provide (e.g. Brewster, 1966). And many employers recruit at universities selectively. They assume that the type of college an individual attended will influence job performance (cf. Rynes \& Boudreau, 1986; Sasaki, 1981). The purpose of this study is to examine this issue. Do university characteristics relate to early job outcomes? More specifically, which characteristics relate to which outcomes? The relationships are examined among university input, context, and output factors and job offers, employment status, job attitudes, and job performance.

Although data are used from a sample of American universities, it is assumed that the data are relevant to universities from other countries. Many of the variables in the study (e.g., size) are those on which distinctions are made among universities across a number of countries (Skolnik, 1986). Other 
variables in the study (e.g., socioeconomic status [SES]) have demonstrated cross-national generalizeability in a variety of settings (Treiman, 1977). Finally, these data may be of particular interest to Canadian universities. While there are differences between the higher educational systems in the U. S. and Canada, the two systems are in close proximity, interact with one another, and share some ideological and structural similarities (Axelrod, 1982; Burn et al., 1971; Sheehan, 1985; Skolnik, 1986).

Most research on the impact of university characteristics has focused on status attainment - that is, how characteristics of colleges relate to the level of SES attained after graduation (e.g., Smart \& Pascarella, 1986). Little research exists on the relationship between university characteristics and job outcomes-that is, behaviours and attitudes manifested at work. Two recent exceptions are studies by Howard (1986) and Ferris (1982).

As part of a larger study, Howard (1986) looked at the relationship between university quality and managerial performance in two samples of AT\&T managers. In one sample (managers hired in the 1950s), she found that individuals from higher quality universities were given higher assessment centre ratings (after they were hired) on intellectual ability, advancement motivation, nonconformity, and general effectiveness. However, university quality did not correlate with career progress until managers had been with the organization for 20 years. For the twenty year veterans, there was a slight, positive correlation between university quality and career progress. In her second sample (managers hired in the 1970s), university quality related to assessment centre ratings on independence and nonconformity, but did not relate to career progress. Ferris (1982) investigated the relationship between university quality and salary level and performance of newly hired, junior level, and senior level accountants in one prestigious, national firm. He found that university quality was slightly related to salary levels, but not related to job performance.

While the Howard and Ferris studies suggest that university characteristics relate to job outcomes, three points should be kept in mind. First, they each collected data from one organization, and thus their results may not generalize to other organizations. Second, they measured only one university characteristic, quality. Third, they measured a limited number of outcomes. In this study, 11 university characteristics and seven job outcomes, including job offers, were measured, and the sample includes individuals from many organizations. 


\section{University Characteristics}

University characteristics can be categorized under three headings: input, context, and output factors. Input factors are the characteristics of students entering a school. Context factors are characteristics of schools that socialize, educate, or in other ways "add value" to students. Output factors are attributes on which students differ upon graduation. Our input factors are SES, ability of entering freshmen, selectivity, and sex composition of the student body; the context factors are control, size, wealth, religious orientation, and religious denomination; and the output factors are cognitive ability at the time of graduation and student grades.

\section{Input}

Socioeconomic status. Universities differ in the SES composition of their student bodies (Astin, 1965). This is probably more true in countries that have traditionally followed a mass education policy. In countries that have followed an elite model, the majority of students have come from upper SES backgrounds (Burn et al., 1971; White \& Ahrens, 1989). However, because of the explosion of knowledge and technology in the late twentieth century, nations that followed elite models of higher education are likely to move closer to the mass education model (White \& Ahrens, 1989). In the post-industrial age, the general level of education throughout a society has an important influence on its economic prowess.

Although SES predicts occupational status (Jencks, 1979) and managerial career progress (Pfeffer, 1978), the relationship between SES and performance is less straightforward (cf. White, 1982). While SES tends to be associated with status attainment, it may have less to do with actual job performance, especially at the early career stage. SES may help in entering some professions, such as public accounting. Students from higher SES backgrounds may appear more poised, they may have social skills and speech patterns that employers value, and their family connections may benefit business development. But after one enters an occupation, it is likely that early career performance has more to do with supervisory expectations, the work environment, and technical skills than SES (e.g., Berlew \& Hall, 1966). Therefore, we expect that SES will be associated with job offers from prestigious firms, but will be unrelated to job attitudes and performance.

Ability of entering freshmen. Universities differ widely in the average level of cognitive ability of their entering freshman classes (Klitgaard, 1985, 
109-111). A considerable amount of research shows that cognitive ability correlates with university grades (Ford \& Campos, 1977), job performance (Hunter, 1986), and career success (Jencks, 1979). Therefore, employers may be more likely to recruit at, and offer jobs to graduates from, universities that admit a majority of bright students. Moreover, graduates from these universities should perform better on the job than graduates from schools where admission standards are lower. We should also note that the average aptitude scores of entering students identify a university's prestige ranking, at least in the United States (Astin \& Lee, 1971).

Selectivity. We define selectivity as the percentage of applicants who are offered admission in a given year. Selectivity is an indication of the control a school has over the composition of its student body. By having a wider variety of applicants from which to choose, universities can select students who meet or exceed admission standards rather than admit whoever applies. Thus, selectivity should correlate with ability of entering freshmen. However, selectivity is more than a proxy for ability of entering freshmen. Because of their large applicant pools, selective universities can engineer the composition of their entering classes on a variety of attributes, such as geographical and cultural background. Winter, McClelland, and Stewart (1981) suggest that diversity of university peers enhances personal maturity, disciplined assertion, and critical thinking abilities. It may also help individuals deal effectively with diversity in the workplace, in interacting with heterogeneous co-workers, superiors, and clients. We expect that students who graduate from selective universities will have more favourable early job outcomes than students who graduate from less selective universities.

Sex composition. The sex composition in universities correlates with the orientations and attitudes of students, as well as with the university climate (Astin, 1965). Universities with a higher proportion of males tend to have more realistic and conventional environments, while universities with a higher proportion of females have more social and artistic environments (Astin, 1965, p. 25). Therefore, we expect that employers from conventional organizations, such as accounting firms, will be more inclined to offer jobs to students from universities with higher proportions of male students. This may be less likely to occur in the future as more females train for and enter the accounting profession. 


\section{Context}

Control. Although not always a precise dichotomy, an important feature of university governance in some countries is whether a university is publicly or privately controlled. Almost all of the universities in Canada and France are public, while there is a mixture of both types in Japan (Burn et al., 1971) and the United States (Skolnik, 1986). In the United States, students in private universities have more interaction with professors, become more familiar with professors in their major field, and are more verbally aggressive than students in public institutions (Astin, 1977, p. 231). This is important in public accounting because junior level accountants frequently deal with middle and upper level managers of client organizations. As such, students from private universities may be less reluctant to interact with authority figures in a job setting. We expect, therefore, that students who graduate from private universities will have more favourable early job outcomes than students who graduate from public universities.

Size. The size of a university, as measured by the number of students enrolled, is one of its most visible characteristics. A primary effect of size on students' educational experience is the degree of attention they receive from faculty. The smaller the university, the more faculty attention students receive (Green et al., 1983); individual attention from faculty results in greater learning (cf. Bloom, 1985) and status attainment (Lacy, 1978). In addition, students from smaller universities have more opportunity to exercise leadership roles, thereby gaining familiarity with such roles (Astin, 1977). Since it is reasonable to assume that student-faculty interaction and intensive learning relate to an individual's performance outside of the classroom, students who graduate from smaller universities should have more favourable early job outcomes than students who graduate from larger universities.

Wealth. For our purposes, the wealth of a university is the amount of financial resources actually directed towards the education of students, that is, the amount of financial resources spent per student per year. Wealth should be positively related to job outcomes for several reasons. It affects a university's ability to hire good faculty, and universities with top reputations have among the highest paid faculty (Astin, 1985). Financial resources allow a university to hire more faculty per student; this often translates into more individualized instruction. University wealth is associated with well-stocked libraries, instructional materials, scientific facilities, and cultural resources and programs. 
Wealthy universities in the United States tend to attract the most able students, as measured by university entrance exam scores (Astin, 1985, p. 40). Therefore, we expect that university wealth will be positively correlated with job outcomes.

Religious orientation and religious denomination. Religious institutions have played an important role in the history of higher education in Western Europe and the Americas (Brubacher \& Rudy, 1976). Several universities still maintain church affiliations in Europe and Canada (Burn et al., 1971), and 24 percent of all universities in the U.S. have religious affiliations (Grant \& Snyder, 1986). Religious orientation is defined as whether or not a university is affiliated with a religious institution. Religious denomination refers to the type of church with which a university is affiliated. The evidence is mixed on the effects of religious orientation and religious denomination (Astin, 1977). Therefore, no specific hypotheses are offered on the effects of these variables on early job outcomes.

\section{Output}

Cognitive ability. Cognitive ability may change over time (Angoff, 1988), including during the university years (Humphreys,1968). Thus, cognitive ability at the time of graduation should reflect, in part, the impact of a university on students' thinking skills; cognitive ability at graduation should also be more relevant to job outcomes than cognitive ability at matriculation. A positive correlation was thus expected between cognitive ability at graduation and job offers and job performance.

Grade point average. In the United States, students' university performance is indexed by a grade point average (GPA). The American GPA is essentially the same as the Canadian percentage grade, although on a different metric. GPA is an index of how well students do academically. Although GPA is a university characteristic that varies among universities (Astin, 1977), it undoubtedly varies more within universities than between universities. It has, however, an important influence on early job outcomes, and therefore should be examined. GPA can influence job outcomes in at least two ways, as a screening device that employers use to make hiring decisions, and as a predictor of job performance. Employers often use GPA to screen job applicants and, therefore, it would seem reasonable that students with higher GPAs would be granted more job interviews and given more job offers (cf. Rynes \& Boudreau, 1986). GPA may also be an indicator of intelligence, motivation, inner work standards, or some 
combination of all three. As such, it should be positively correlated with performance on the job. A positive correlation was thus expected between GPA and job offers and job performance.

\section{Method}

\section{Setting and Subjects}

This study was partially sponsored by eleven offices of eight prestigious accounting firms in the southwestern United States in order to learn more about the effects of their recruiting practices. At the time of this study, the eight accounting firms were the largest professional service organizations in the world in terms of number of partners, number of staff, annual revenues, or any other reasonable size measure. As such, they dominated the field of accounting-related and consulting services in the United States and in every other developed nation in the world. These firms were informally known as the "Big Eight." Since this study was conducted, four of the "Big Eight" firms merged into two firms. There are now six top-tier accounting firms.

Because this study was sponsored by firms in the southwestern United States, we collected data from: (1) accounting students who attended universities primarily in the southwest and (2) individuals who accepted employment with a "Big Eight" accounting firm participating in the study. Figure 1 illustrates the sampling procedure and gives the number of subjects included in the samples at different times throughout the study.

Sample One. The subjects in Sample One were seniors in accounting programs when their participation in the study began. The study initially surveyed 1,424 seniors. They were accounting majors from eighteen universities located primarily in the southwest United States. These were the universities from which the 11 offices in our study recruited the majority of their new employees. Consequently, there was a good probability that some of the students initially surveyed would also end up working for the firms in the study. Forty-seven percent of the subjects were male, 72 percent were between 20 and 24 years old, 92 percent were white, and 96 percent were accounting majors.

Sample Two. When their participation in the study began, the subjects in Sample Two had just started to work as entry-level accountants at "Big Eight" accounting firms in the southwest. Data were initially collected from 468 accountants at the offices of the "Big Eight" accounting firms. These new 
Figure 1

Sampling Procedure

\begin{tabular}{|c|c|c|c|c|c|}
\hline & Fall 1982 & Summer 1983 & Fall 1983 & Summer 1984 & Fall 1984 \\
\hline \multirow[t]{2}{*}{ Sample 1} & $\begin{array}{l}\text { Senior Accounting } \\
\text { Majors Surveyed } \\
\text { At } 18 \text { Universities }\end{array}$ & & $\begin{array}{l}\text { Subjects Surveyed } \\
\text { at their Homes }\end{array}$ & & \\
\hline & $\mathrm{N}=1,424$ & & Response: $\mathrm{N}=605$ & & \\
\hline Sample 2 & & $\begin{array}{l}\text { Newly-hired Account- } \\
\text { ants Surveyed at First } \\
\text { Day of Work At Eleven } \\
\text { "Big Eight" Accounting } \\
\text { Firms }(\mathrm{N}=468) \\
96 \text { Universities Repre- } \\
\text { sented. } \\
\text { Those who did not } \\
\text { attend Graduate School: } \\
\mathrm{N}=360\end{array}$ & & $\begin{array}{l}\text { Subjects surveyed at } \\
\text { Work } \\
\text { Response: } \mathrm{N}=280\end{array}$ & $\begin{array}{l}\text { Performance } \\
\text { Ratings from } \\
\text { Supervisors } \\
\text { Response: } \\
\mathrm{N}=395\end{array}$ \\
\hline
\end{tabular}


accountants represented 96 universities, and each of the "Big Eight" firms was represented. Because this study focuses on undergraduate institutions, only those subjects were included who did not attend graduate school $(n=360)$. Of these subjects, 54 percent were male, 91 percent were between the ages of twenty and twenty-four, 94 percent were white, and 89 percent were accounting majors.

\section{Analysis Sample}

The analysis sample $(n=198)$ consisted of subjects on whom data were obtained at two points in time, that is, subjects on whom data were obtained before graduation from universities and/or at the time they started work, and on whom we have data approximately one year after graduation. Subjects in the analysis sample represented 82 universities. These represent a wide cross section of universities in the United States. Fifty-six percent of these subjects were male, 93 percent were between the ages of twenty and twenty-four, 97 percent were white, and 85 percent were accounting majors.

\section{Procedure}

Table 1 summarizes the instruments used, the nature of the data, and when and where the data were collected.

Table 1

\section{Data Collection}

\begin{tabular}{lc}
\hline \multicolumn{1}{c}{ Instrument } & When \& Where Administered \\
\hline $\begin{array}{l}\text { Questionnaire One } \\
\text { (Background information) }\end{array}$ & Fall 1982 \\
Questionnaire Two & Universities on site \\
(Background information) & Summer 1983 \\
Aptitudes Tests & Accounting Firms, on site \\
Questionnaire Three & Accounting Firms, on site \\
(Current employment status) & Fall 1983 \\
Questionnaire Four & Subjects' homes, mailed \\
(Job attitudes) & Summer 1984 \\
Supervisor Performance Ratings & Accounting Firms, mailed \\
& Fall 1984 \\
& Accounting Firms, mailed \\
\hline
\end{tabular}


The first wave of data was collected in the Fall of 1982 at eighteen universities located predominately in the southwestern United States. These universities had large undergraduate accounting programs and were universities from which accounting firms and corporations recruited new accountants. After securing permission of the chairpersons of the accounting departments, two of the authors and several research assistants administered Questionnaire One to accounting students in their senior year. This questionnaire included items related to subjects' background and education.

In the summer of 1983, one of the authors administered Questionnaire Two to subjects in Sample Two on their first day at work. Questionnaire Two was similar to Questionnaire One, and it was administered to subjects in groups during orientation sessions. Immediately following, the researcher administered aptitude tests under standardized conditions.

Several months later, during the Fall of 1983, Questionnaire Three was mailed to the subjects in Sample One who were not in Sample Two. This questionnaire, mailed to subjects' homes, asked subjects about their current employment status and career goals. Subjects were asked to mail their completed questionnaire to a university address, and 605 questionnaires were received (42 percent response).

Questionnaire Four was mailed to subjects in Sample Two in the summer of 1984, after they had been employed about a year. This questionnaire, mailed to subjects' offices, included items about job attitudes. Subjects were asked to mail their completed questionnaires to a university address, and were assured that individual responses would be confidential and anonymous. Two hundred and eighty questionnaires were received ( 60 percent response).

A few months later, a performance measurement questionnaire and cover letter were mailed to supervisors of subjects in Sample Two. It requested first year performance ratings, and asked additional questions on performance, promotability, and turnover. Again, anonymity was assured, and supervisors were asked to mail their completed questionnaires to a university address. Completed rating forms were received from 395 supervisors ( 84 percent response).

\section{Measures}

Input factors. Hollingshead and Redlich's (1958) measure of socioeconomic status was adapted, and included on the second questionnaire. It consists of items measuring the occupational and educational status of the subject's father 
and mother. The highest parental SES score was used to index subjects' SES level. The academic ability of entering freshmen was estimated from the average total Scholastic Aptitude Test (SAT) scores or the average composite American College Test (ACT) scores of entering freshmen for each institution. Almost all universities in the United States use scores from one or the other of these tests, along with other information, in evaluating university applicants. The SAT is an aptitude test focusing on verbal and mathematical aptitudes. The ACT is an achievement test that measures understanding and usage of the English language, mathematics, social studies, and natural sciences. The average test scores from universities in our samples were obtained from the twelfth edition of American Universities and Colleges (American Council on Education, 1983). Because most American universities require SAT or ACT scores, a single index of academic ability was constructed using the following procedure. First, Langston and Watkins' (1980) conversion tables were used to equate SAT total and ACT composite scores. Second, ranges were ranked into ten categories. A score of one corresponded to SAT total scores of 699 or below and ACT composite scores of fourteen or below; the scores graduated to ten, with ten corresponding to SAT total scores of 1,200 or above or ACT scores of twenty nine or above. College selectivity was measured by the percentage of applicants who were admitted for the 1979 academic year. This figure was subtracted from 100 so that higher selectivity would be associated with a higher number. Sex composition was indexed by the percentage of males enrolled.

Context factors. Subjects were asked to indicate the name of their undergraduate institution on Questionnaires One and Two, as well as university major and degree received. Most of the information on context factors was obtained from the 12 th edition of American Universities and Colleges (American Council on Education, 1983). In general, the information for this edition was for the 1980-81 academic year, the year when most subjects in the study were sophomores. Information was gathered for every American university represented by subjects in Samples One and Two. Institutional control was categorized as public or private governance. Size was indexed by the total number of students enrolled during the academic year, and university wealth was measured by the ratio of the annual operating budget to the number of students enrolled. Religious orientation was coded as secular or religious, and religious denomination as Protestant or Catholic.

Output factors. The verbal and reasoning scales of the Ball Aptitude Battery 
(Layton, 1985) were used to measure cognitive ability. Alternate form reliability for the verbal scale is .98 and test-retest reliability for the reasoning scale is .71 . The verbal and reasoning scales correlated modestly $(\underline{r}=.25)$, and were combined into a composite scale. GPA was obtained by self-report on Questionnaire Two. GPAs were indexed on a scale from 0 to 4 . A 0 is equivalent to the grade of " $F$ " and a 4 is equivalent to the grade of "A." The zero-order correlations among input, context, and output factors are presented in Table 2.

Job outcomes. Two measures of job offers and one measure of employment status were used. Total number of job offers was calculated by summing the responses to a checklist of job offers on Questionnaire Two. Subjects were asked to indicate the job offers they received from a list of twenty two accounting firms and oil companies which were large employers of accounting graduates in the Southwest. This information was available from subjects in Sample Two.

Subjects were coded as having received a job offer from a "Big Eight" firm if they were (a) employed by a "Big Eight" firm, or (b) received a job offer from a "Big Eight" firm but were not employed by one. Two variables were created in order to examine the results with combined samples and with Sample One alone. For the first variable, all subjects in Sample Two were coded as having received a job from a "Big Eight" firm; subjects in Sample One indicated on Questionnaire Three if they had received a job offer from a "Big Eight" firm. For the second variable, only subjects in Sample One were used, and responses to the job offer item on Questionnaire Three.

Three categories were created for employment status: (1) "Big Eight" accounting firm, (2) non-"Big Eight" accounting firm, and (3) a non-accounting organization (e.g., a manufacturing organization). All subjects in Sample Two were employed in a "Big Eight" accounting firm. For subjects in Sample One, an item on Questionnaire Three provided information on where they were employed.

Job performance was measured by a composite of subjects' annual performance rating and the two following questions on the performance questionnaire sent to supervisors: "Would you rehire this person to work for you if he or she were to quit?" (anchored from one, "definitely not" to five, "definitely yes") and "In general, how easy would it be to find someone who would do as good a job as this person is doing (anchored from one "very easy" to five "very difficult"). The coefficient alpha for the three measures was .78. 
Table 2

Correlations among University Characteristics

\begin{tabular}{|c|c|c|c|c|c|c|c|c|c|c|c|}
\hline College & Characteristics & 1 & 2 & 3 & 4 & 5 & 6 & 7 & 8 & 9 & 10 \\
\hline \multicolumn{12}{|l|}{ Input } \\
\hline 1. & \multicolumn{11}{|l|}{ Socioeconomic Status } \\
\hline 2. & \multicolumn{11}{|c|}{ Academic ability of entering 13} \\
\hline 3. & Selectivity & 09 & $83 * *$ & & & & & & & & \\
\hline 4. & Sex Composition & & 03 & $83^{* *}$ & $74 * *$ & & & & & & \\
\hline \multicolumn{12}{|c|}{ Context } \\
\hline 5. & Control & 13 & $60^{* *}$ & $49^{* *}$ & $31 * *$ & & & & & & \\
\hline 6. & Religious orientation & 10 & $58 * *$ & $47 * *$ & $30 * *$ & $98^{* *}$ & & & & & \\
\hline 7. & Religious denomination & 03 & $88 * *$ & $93^{*}$ & $95^{* *}$ & - & - & & & & \\
\hline 8. & Size & 00 & $16^{* *}$ & $-06^{*}$ & $07 * *$ & $-59 * *$ & $-57^{* *}$ & $37 * *$ & & & \\
\hline 9. & Wealth & $12^{*}$ & $90 * *$ & $82 * *$ & $73 * *$ & $37^{* *}$ & $33 * *$ & $90 * *$ & $13 * *$ & & \\
\hline 10. & $\begin{array}{l}\text { Cognitive ability upon } \\
\text { graduation }\end{array}$ & 04 & $18^{*}$ & $13 *$ & -01 & 10 & 03 & 09 & -10 & 08 & \\
\hline 11. & Grade point average & 03 & -07 & -02 & $-09 * *$ & $08^{*}$ & $07^{*}$ & $-17 * *$ & $-15 * *$ & -05 & $30^{* *}$ \\
\hline \multicolumn{12}{|c|}{ Note: Decimals are omitted $\quad * \mathrm{p}<.05 ; * * \mathrm{p}<.01$} \\
\hline
\end{tabular}


Promotability was measured by a single item: "How promotable is this person?" It was anchored from one ("definitely not promotable") to five ("has recently been promoted").

Job satisfaction and organizational commitment were measured on Questionnaire Four. Job satisfaction was assessed by a five-item scale from the Job Diagnostic Survey (JDS; Hackman \& Oldham, 1980) (alpha = .77), organizational commitment by the Porter, Steers, Mowday, and Boulian (1974) scale (alpha $=.88$ ), and internal work motivation by a six-item scale from the JDS (alpha $=.67)$.

\section{Results}

\section{Correlational Analyses}

Table 3 shows the correlations among university characteristics and job outcomes. Religious denomination and GPA correlated positively with total number of job offers. Almost all university characteristics correlated positively with receiving a job offer by a "Big Eight" firm.

None of the university characteristics correlated with internal work motivation, job satisfaction, or organizational commitment. Ability of entering freshmen correlated negatively with promotability and job performance. Cognitive ability at graduation and GPA correlated with promotability and job performance.

Multiple regression in the analyses was precluded because of multicollinearity among a number of the independent variables. Regression coefficients may be highly misleading when multicollinearity exists (Cohen \& Cohen, 1975).

\section{University Characteristics and Employment Status}

Table 4 presents the university characteristic means by employment status. Scheffé comparisons revealed that subjects employed in "Big Eight" firms had significantly higher mean scores than subjects in other accounting firms or non-accounting organizations on ability of entering freshmen, selectivity, wealth, and GPA. Subjects employed in "Big Eight" firms had significantly higher mean scores than subjects employed in non-accounting organizations (but not in other accounting firms) on sex composition (more males), private control, and Catholic religious orientation. 
Table 3

Correlations Between University Characteristics and Job Outcomes

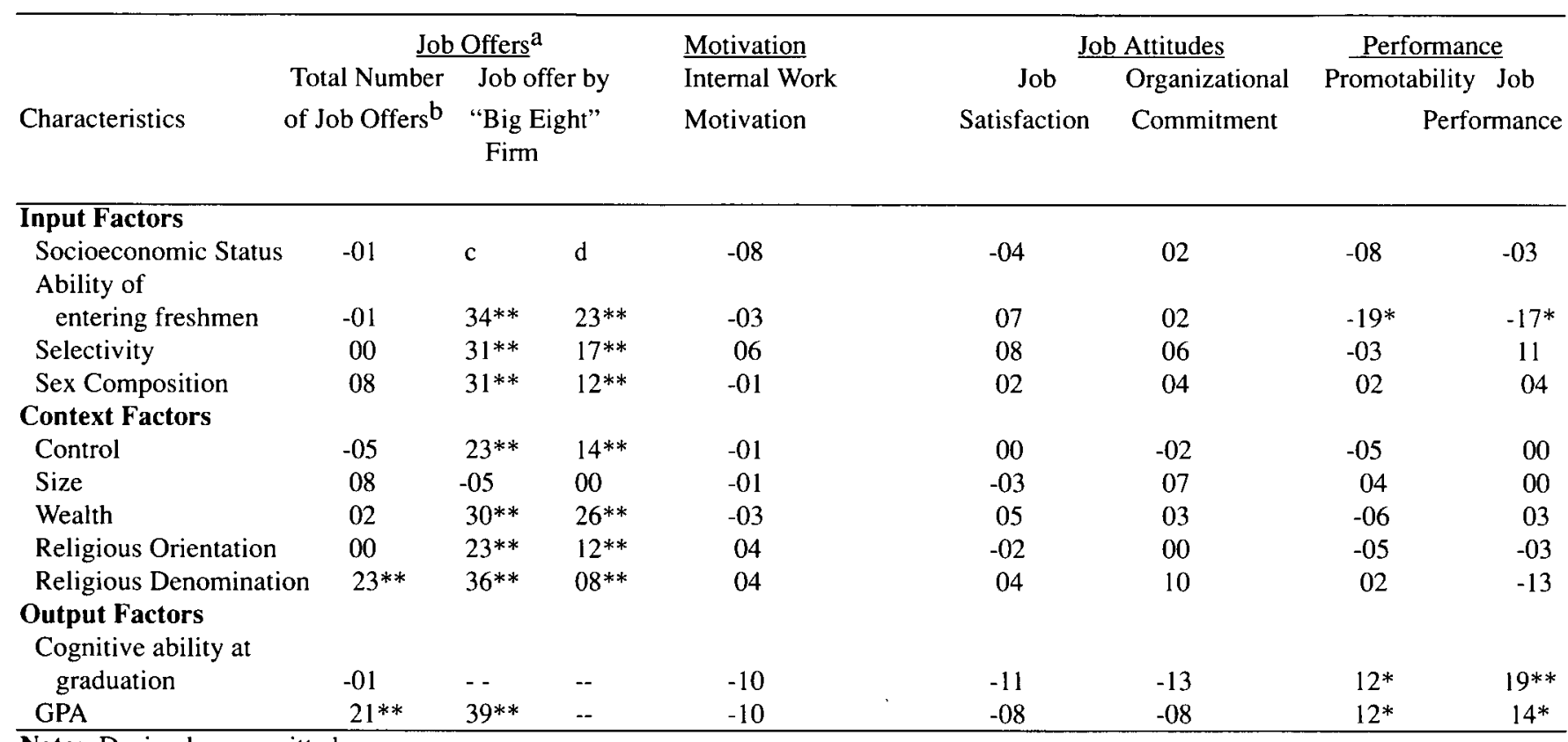

Note: Decimals are omitted.

${ }^{*} \mathrm{p}<.05 ; * * \mathrm{p}<.01$

a No offer from a "Big Eight" firm, 2 = an offer from a "Big Eight" Firm.

b The total number of job offers received by subjects in Sample Two.

${ }^{c}$ These correlations are based on responses by subjects in Sample One.

$\mathrm{d}$ These correlations are based on responses by subjects in Samples One and Two. 
Table 4

Mean University Characteristics by Employment Status

\begin{tabular}{|c|c|c|c|}
\hline Characteristic & $\begin{array}{c}\text { "Big Eight" } \\
\text { Accounting Firm }\end{array}$ & $\begin{array}{l}\text { Other } \\
\text { Accounting Firm }\end{array}$ & $\begin{array}{l}\text { Non-Accounting } \\
\text { Organization }\end{array}$ \\
\hline \multicolumn{4}{|l|}{ Input } \\
\hline $\begin{array}{l}\text { Ability of entering } \\
\text { freshmen }\end{array}$ & 7.77 & $6.60^{*}$ & $6.69 *$ \\
\hline Selectivity & 29.13 & $23.03 *$ & $22.03^{*}$ \\
\hline $\begin{array}{l}\text { Sex composition }{ }^{\mathrm{a}} \\
\text { Context }\end{array}$ & 56.92 & 56.17 & $54.17^{*}$ \\
\hline Control $^{b}$ & 1.35 & 1.23 & $1.21 *$ \\
\hline Size $^{\mathrm{c}}$ & 21.81 & 19.64 & $21.92 *$ \\
\hline Wealth $\mathrm{c}$ & 6.61 & $5.64 *$ & $5.59 *$ \\
\hline Religious orientation ${ }^{d}$ & 1.32 & 1.23 & $1.21^{*}$ \\
\hline $\begin{array}{l}\text { Religious denomination } \mathrm{e} \\
\text { Output }\end{array}$ & 1.39 & 1.48 & 1.30 \\
\hline GPA & 3.46 & $3.20^{*}$ & $3.07 *$ \\
\hline
\end{tabular}

*Significantly different from "Big Eight" Accounting Firm at $\mathfrak{p}<.05$

a Percent male

b 1 = Public, 2 = Private

c In thousands

d $1=$ Secular, 2 = Religious

e 1 = Protestant, 2 = Catholic

\section{Discussion}

This research examined whether university characteristics are related to early job outcomes, in particular, job offers, employment status, job attitudes, and job performance. No significant relationships emerged between university characteristics and job attitudes, and there were only weak relationships between university characteristics and job performance. There were, however, numerous relationships between university characteristics and job offers and employment status.

That most university characteristics were unrelated to job performance is a surprising — and important - finding. Two explanations might be offered. First, as Jensen (1986) notes, once individuals meet an educational or cognitive 
threshold for an occupation, they should have the ability to perform successfully. Subjects in these samples probably met the minimum ability threshold for the accounting profession, given that they graduated from a university with a degree in accounting. Second,when there is little variation in the abilities of employees, situational factors should have the strongest influence on job performance. For example, supervisors' expectations (Eden \& Shani, 1982), performance feedback (Latham \& Wexley, 1981), and the working environment (Oldham, Hackman, \& Pearce, 1976) should have a stronger influence on job performance than where one went to university.

Yet why were there significant correlations between university characteristics and job offers from and employment at prestigious accounting firms? Five explanations might be offered, none of which is necessarily exclusive of the others.

First, company recruiters may believe that university characteristics relate to applicants' performance potential, and they make job offers accordingly. University characteristics may be taken as indicative of general skill or ability (cf. Berger, Cohen, \& Zelditch, 1966). The social psychological basis for this is balance theory (Kimberly, 1970). In the absence of specific knowledge to the contrary, the attribution of a specific characteristic would follow from knowledge of a diffuse characteristic. For example, a company recruiter might attribute accounting skill from the prestige of the applicant's alma mater.

Second, the university pedigree of a firm's employees sends signals to its clients. Accounting firms have equivocal standards of performance, yet they must maintain a high degree of public confidence. They can enhance their image of competence and trustworthiness through the effective use of symbols. One symbol that may communicate these attributes is the educational pedigree of their employees (Collins, 1979; Klitgaard, 1985, pp. 118-119).

Third, individuals from particular types of universities may be effective at generating new clients. For example, individuals with elite educational credentials are disproportionally represented on the boards of large corporations (Cookson \& Persell, 1985, pp. 195-201). Thus, accountants with elite educational credentials may have greater access to potential clients.

Fourth, because people prefer to interact with others who have similar values and attitudes (Secord \& Backman, 1964), an organization's leaders may feel comfortable working with individuals from similar backgrounds. People with similar characteristics tend to enrol in similar types of universities (Astin, 1965), and similar types of universities tend to have a similar influence on students' attitudes (Astin, 1984). Because individuals' backgrounds and values 
influence how they interpret events, people who share similar backgrounds should communicate and, therefore, work more effectively with one another (Colarelli \& Boos, in press; Turban \& Jones, 1988). Therefore, partners in accounting firms may favour hiring people who graduated from the same universities, or same types of universities, that they attended.

Finally, people need to believe that they can predict and control life's events, even if they have little control (Heider,1958). To provide a sense of control, organizations may attend to areas which they can control (e.g., where to recruit and the type of applicants to hire), even if such activities have little payoff.

\section{Limitations}

A few of the results may not generalize directly to universities in other countries. For example, the U. S. has a larger percentage of private and religiously affiliated universities than Canada or European countries (Skolnik, 1986). However, these results may have comparative significance in the deeper meanings of private control and religious affiliation. Private control in the U.S. often reflects wealth and status (Hall, 1982), and religious affiliation reflects codes of moral values (Winter, et al., 1981). Thus, the results related to control may reflect a more universal phenomenon of wealth and status, and the results related to religious affiliation may reflect a deeper issue of value orientation. Other characteristics in this study should generalize in a straightforward way. These are characteristics that have similar meanings or structural effects across cultures. They include SES, academic ability of entering students, selectivity, sex composition, size, wealth, and performance in university (GPA).

Although the results of this study are from accountants, they should generalize to other technical professions, especially those where credentialing occurs at the bachelor's level. Generalizing to the population of young accountants can also be done with confidence. Almost all of the men and women in this study were accounting majors, from a variety of universities, who entered the accounting profession. However, caution is warranted on two accounts. First, because this study focuses on early job outcomes, different results may be found for middle or late career outcomes. And second, the results of this study apply to the characteristics that were measured. Although the study measured what the literature suggests are key university characteristics, there are other characteristics that were not measured. Other characteristics may relate differently to job outcomes. 


\section{Implications}

The findings have implications for students, people who advise students, and university recruiters. The results show that university characteristics influence job opportunities: many characteristics helped to open doors to prestigious firms. On the other hand, where one goes to university is minimally related to performance on the job. Advisors can, therefore, suggest to students that their performance on the job will be determined primarily by job conditions and job skills, not by where they went to university. However, where one attends university can have a significant effect on one's career opportunities.

This study also shows that university recruiters can find capable employees in many types of universities. Therefore, they may benefit from designing recruiting programs on the basis of logistical advantages, student demographics, or the type of programs a university offers. Also, by expanding recruiting efforts, organizations can increase the size of their applicant pools; this should improve the utility of their selection programs.

Since the study's results do not support the position that differences in university characteristics relate to job performance, they suggest that job performance is not a strong argument for university diversity. Rather, the value of diversity is in matching student needs with institutional climates, giving legitimization to subcultures in pluralistic societies, and facilitating the efficient use of scarce and specialized resources (Skolnik, 1986).

Finally, it must be emphasized that these findings do not speak to the relationship between university characteristics and the learning process or university life. They do, however, add evidence to the debate over value-added assessment of higher education (Cicarelli, 1987). This study indicates that universities similar to those examined add about the same value to students' reservoirs of specific job skills. Therefore, basic abilities and broad knowledge may be the most appropriate criteria for assessing the quality of undergraduate education, including undergraduate education in business (Kapoor \& Chan, 1985).

\section{References}

Angoff, W. H. (1988). The nature-nurture debate, aptitudes, and group differences. American Psychologist, 43, 713-720.

American Council on Education. (1983). American Universities and Colleges. (12th ed.). New York: Walter de Gruyter.

Astin, A. W. (1985). Achieving Educational Excellence. San Francisco: Jossey-Bass. 
Astin, A. W. (1977). Four Critical Years. San Francisco: Jossey-Bass.

Astin, A. W. (1965). Who Goes Where to College? Chicago: Science Research Associates.

Astin, A. W., \& Lee, C. B. T. (1971). The invisible colleges. New York: McGraw-Hill.

Axelrod, P. (1982). Scholars and dollars: Politics, economics, and the universities of Ontario 1945-1980. Toronto: University of Toronto Press.

Bauer, B., \& Others. (1988). America's Best Colleges. U. S. News \& World Report, October 10 C3-C32.

Berger, J., Cohen, B. P., \& Zelditch, R., Jr. (1966). Status characteristics and expectations states. In M. Zelditch and B. Anderson (Eds.), Sociological Theories in Progress: Vol. I, 29-46. New York: Houghton Mifflin.

Berlew, D. E., \& Hall, D. T. (1966). The socialization of managers: Effects of expectations on performance. Administrative Science Quarterly, 11, 207-223.

Bloom, B. S. (Ed.). (1985). Developing Talent in Young People. New York: Ballantine Books.

Brewster, K. (1966). Admission to Yale: Objectives and myths. Yale Alumni Magazine, October 31-32.

Brubacher, J. S., \& Rudy, W. (1976). Higher education in transition: A history of American colleges and universities, (3rd ed.). New York: Harper \& Row.

Burn, B. B., Altbach, P. G., Kerr, C., \& Perkins, J. A. (1971). Higher education in nine countries. New York: McGraw-Hill.

Carnegie Foundation for the Advancement of Teaching.(1986). How do Students Choose a College? Change, 18, January/February, 29-32.

Cicarelli, J. (1987). A new debate is joined over an old question: Is college an investment or an end in itself? Chronicle of Higher Education, 33, January 7, 128.

Church, H.J., \& Gillingham, D. W. (1985). Situational position and student choice criteria. The Canadian Journal of Higher Education, 15, 31-51.

Cohen, J., \& Cohen, P. (1975). Applied multiple regression/correlation analysis for the behavioral sciences. New York: Lawrence Erlbaum.

Colarelli, S. M., \& Boos, A. (in press). Sociometric and ability-based assignment to workgroups: Some implications for personnel selection. Journal of Organizational Behavior.

Collins, R. (1979).The credential society. New York: Academic Press.

Cookson, P. W., Jr. \& Persell, H. (1985). Preparing for power. New York: Basic Books.

Eden, D., \& Shani, A. B. (1982). Pygmalion goes to boot camp: Expectancy, leadership, and trainee performance. Journal of Applied Psychology, 67, 194-199.

Ferris, K. R. (1982). Educational predictors of pay and performance. Accounting, Organizations and Society, 7, 225-230.

Ford, S. F., \& Campos, S. (1977). Summary of validity data from the admissions program validity study service. Princeton: College Entrance Examination Board.

Grant, W. V., \& Snyder, T. D. (1986). Digest of educational statistics: 1985-1986. Washington, D.C.: U.S. Government Printing Office. 
Green, K. C., \& Others. (1983). The American college student 1982: National norms for 1978 and 1980 college freshmen. Los Angeles: American Council on Education and the Higher Education Research Institute, University of California.

Hackman, J. R., \& Oldham, G. R. (1980). Work redesign. Reading, MA: Addison-Wesley.

Hall, P. D. (1982). The organization of American culture: Private institutions, elites, and the origins of American nationality. New York: New York University Press.

Heider, F. (1958). The psychology of interpersonal relations. New York: Wiley.

Howard, A. (1986). College experiences and managerial performance. Journal of Applied Psychology, 71, 530-552.

Hollingshead, A. B., \& Redlich, F. C. (1958). Social class and mental illness: A community study. New York: John Wiley.

Humphreys, L. G. (1968). The fleeting nature of the prediction of college academic success. Journal of Educational Psychology, 59, 375-380.

Hunter, J. E. (1986). Cognitive ability, cognitive aptitudes, job knowledge, and job performance. Journal of Vocational Behavior, 29, 340-362.

Jencks, C. (1979). Who gets ahead? New York: Basic Books.

Jensen, A. R. (1986). g: Artifact or reality. Journal of Vocational Behavior, 29, 301-331.

Jones, L. V., Lindzey, G. \& Coggeshall, P. H. (Eds.). (1982). An assessment of research-doctorate programs in the United States. Washington, D.C.: National Academy Press.

Kamens, D. H. (1977). Legitimating myths and educational organization: The relationship between organizational ideology and formal structure. American Sociological Review, 42, 208-219.

Kapoor, M. R., \& Chan, K. H.(1985). Education of the professional accountant: An empirical study. The Canadian Journal of Higher Education, 15, 53-73.

Kimberly, J. C. (1970). The emergence and stabilization of stratification in simple and complex social systems. In E. O. Laumann (Ed.), Social stratification: Research and theory for the 1970s. Indianapolis, IN: Bobbs-Merrill, pp 73-101.

Klitgaard, R. (1985). Choosing Elites. New York: Basic Books.

Lacy, W. (1978). Interpersonal relationships as mediators of structural effects: College student socialization in a traditional and an experimental university environment. Sociology of Education, 51, 201-211.

Langston, I. W, \& Watkins, T.B. (1980). SAT-ACT equivalents. Research Memorandum 80-5. Champaign: University of Illinois, University Office of School and College Relations.

Latham, G. P., \& Wexley, K. N. (1981). Increasing productivity through performance appraisal. Reading, MA: Addison-Wesley.

Layton, W. L. (1985). Review of the Ball aptitude battery. In J. V. Mitchell, Jr. (Ed.), The ninth mental measurements yearbook (Vol. 1, pp. 123-125). Lincoln: University of Nebraska, Buros Institute of Mental Measurements. 
Oldham, G. R., Hackman, J. R. \& Pearce, J. L. (1976). Conditions under which employees respond to enriched work. Journal of Applied Psychology, 61, 395-403.

Pfeffer, J. (1977). Effects of an MBA and socioeconomic origins on business school graduates' salaries. Journal of Applied Psychology, 62, 698-705.

Porter, L. W., Steers, R. W., Mowday; R. T., \& Boulian, P. V. (1974). Organizational commitment, job satisfaction, and turnover among psychiatric technicians. Journal of Applied Psychology, 59, 603-609.

Rosenthal, R. A., \& Jacobson, L. (1968). Pygmalion in the classroom: Teacher expectation and pupils' intellectual development. New York: Holt, Rinehart, and Winston.

.Rynes, S. L., \& Boudreau, J. W. (1986). College recruiting in large organizations: Practice, evaluation, and research implications. Personnel Psychology, 39, $729-757$.

Sanders, N. F. (1986). The college selection process. Journal of College Admissions, Spring, 24-27.

Sasaki, N. (1981). Management and industrial structure in Japan. Oxford, England: Pergamon.

Secord, P. F., \& Backman, C. W. (1964). Social Psychology. New York: Mçraw-Hill.

Sheehan, N. (1985). History of higher education in Canada. The Canadian Journal of Higher Education, 15, 25-38.

Skolnik, M. L. (1986). Diversity in higher education: The Canadian case. Higher Education in Europe, 11, 19-32.

Smart, J. C., \& Pascarella, E. T. (1985). Socioeconomic achievements of former college graduates. Journal of Higher Education, 57, September/October, 529-549.

Treiman, D. J. (1977), Occupational prestige in comparative perspective. New York: Academic Press.

Turban, D. B., \& Jones, A. P. (1988). Supervisor-subordinate similarity: Types, effects, and mechanisms. Journal of Applied Psychology, 73, 228-234.

White, E. M., \& Ahrens, R. (1989). European vs. American education. Change, September/October, 51-55.

White, K. R. (1982). The relation between socioeconomic status and academic achievement. Psychological Bulletin, 91, 461-481.

Winter, D. G., McClelland, D. C. \& Stewart, A. J. (1981). A new case for the liberal arts. San Francisco: Jossey-Bass. 